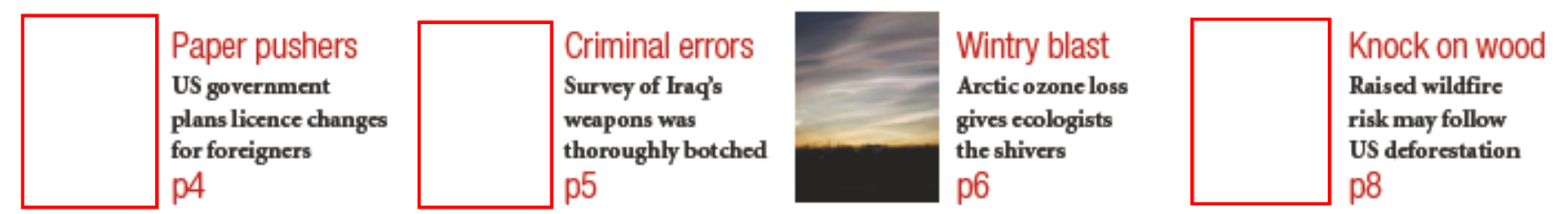

Pesticide results help China edge
transgenic rice towards market

DavidCyranoski

China is poised to commercialize genetically modified rice, possibly within a year. Data have just been published that advocate the rice's health benefits, but observers are concerned by the lack of longterm health and environmental studies, and by evidence that transgenic rice is already being sold illegally in the country.

China has four varieties of genetically modified rice in the final stages of field trials. Last week, Chinese and US researchers presented evidence that two of them-GM Xianyou 63 and GM II-Youming 86 - decrease the Farmers in China may already be trading in illegal transgenic rice.
IMAGE

UNAVAILABLE FOR COPYRIGHT REASONS biologist at the University of Oxford, UK, noting that similar advantages have been seen in the transgenic cotton that is already on sale. "It's nothing new except that it's in rice, ${ }^{,}$he says.

But results such as Huang's could change perceptions about the costs and benefits of genetically modified food, says Robert Ziegler, who became directorgeneral of the non-profit International Rice Research Institute in Los Baños, Philippines, earlier this year. "These hard data are consistent with the objectives that create these materials," he says. "It's not hype. It's real."

Selling genetically modified rice in China competitiveness internationally and rural incomes domestically, the authors write.

The results do sound impressive. GM Xianyou 63 and GM II-Youming 86 contain genes from the Bacillus thuringiensis bacterium and the cowpea, respectively, which make them resistant to two serious pests, stem borers and leaf rollers. Farmers in eight villages in the Hubei and Fujian provinces were given either conventional seeds or the transgenic varieties, all at the same price, and were then told to apply pesticides as needed.

There was a slight increase in productivity of about $6 \%$. But it is the $80 \%$ drop in pesticide use that would bring both economic and health benefits, says the paper's lead author, Jikun Huang, an agricultural economist at the Chinese Academy of Sciences in Beijing.

\section{Lesser poison}

There are no studies showing the extent of pesticide-related illness in China, but according to Huang's unpublished estimates, around 50,000 farmers suffered pesticide poisoning each year in the 1990 s, and around $1 \%$ of those died. Questionnaires submitted by the farmers in the latest survey showed that no households using the transgenic rice suffered symptoms of pesticide-related illness, whereas up to $8.3 \%$ of those using conventional rice did.

The drop in pesticide usage is not in itself a huge surprise, says Chris Leaver, a plant could lead to the acceptance of other crops, and other countries may follow suit, says Leaver: "This is just the tip of the iceberg." Huang confirms that scientists from Vietnam and Indonesia have contacted him about plans to introduce the pest-resistant rice.And progress is being made with Golden Rice, a transgenic strain that aims to combat malnutrition by producing extra pro-vitamin A (see J.A. Paine etal., Nature Biotechnol. 23,482-487; 2005).

But it is not all good news. Some observers are concerned that the Chinese government may use Huang's results to justify approval of the transgenic strains, although few if any studies have been done on their long-term health or environmental effects. And they fear that lax regulation in China might cause problems. Transgenic rice already seems to be popping up illegally in markets in Hubei - GM Xianyou 63 is "probably"being sold there, admits Huang.

${ }^{\alpha}$ Unregulated distribution would definitely happen within the country and across borders," says a Japanese plant biologist and advocate of genetic modification, who asked not to be named. He worries that unregulated distribution could lead to ecologically unbalanced agriculture. $\mathrm{He}$ argues that distribution of transgenic crops should come only after farmers have been educated about the technology and its possible risks. 